\title{
Prothrombin Activity Measurement
}

National Cancer Institute

\section{Source}

National Cancer Institute. Prothrombin Activity Measurement. NCI Thesaurus. Code C98774.

The determination of the biological activity of prothrombin in a sample. 